Bull. Chem. Soc. Ethiop. 2021, 35(2), 273-286.

(C) 2021 Chemical Society of Ethiopia and The Authors

ISSN 1011-3924

DOI: https://dx.doi.org/10.4314/bcse.v35i2.5

Printed in Ethiopia

Online ISSN 1726-801X

\title{
REMOVAL OF MERCURY(II) BY TRI n-BUTYL PHOSPHATE BASED SUPPORTED LIQUID MEMBRANE
}

\author{
Saravanan Ayyavoo ${ }^{1,2^{*}}$ and Sankar Ramasamy ${ }^{2}$ \\ ${ }^{1}$ WCTP, TPS II Expansion, NLC India Ltd, Neyveli, Cuddalore-607801, India \\ ${ }^{2}$ Department of chemistry, University College of Engineering Villupuram, Anna University, \\ Chennai-600 025, India
}

(Received October 29, 2020; Revised October 6, 2021; Accepted October 6, 2021)

\begin{abstract}
Mercury even at a trace level poses a significant threat to the environment and the ecosystem. Thus, prompting the need to develop a technology to separate mercury(II) selectively from aqueous solutions. The removal of mercury(II) from aqueous solutions using tri n-butyl phosphate (TBP) based supported liquid membrane (SLM) was investigated in this study. $\mathrm{HCl}$ and $\mathrm{NaOH}$ were used as feed and strip phases, respectively. Factors considered for designing the experiments using the Taguchi method include feed phase acid concentration, strip phase alkali concentration, carrier concentration and initial feed phase mercury(II) concentration. The results indicated that carrier concentration was the most influential factor on the removal efficiency. The percentage contribution of each factor was calculated. The results show that carrier concentration and initial feed phase mercury(II) concentration have a maximum contribution. For the maximum removal of $91.7 \%$ of mercury(II) (initial concentration $-10 \mathrm{mg} / \mathrm{L}$ ) in the feed phase, the optimum conditions were $0.3 \mathrm{M}$ of $\mathrm{HCl}, 0.2 \mathrm{M}$ of $\mathrm{NaOH}$, and $90 \%$ of TBP. SEM analysis was performed to evidence the transportation process through the membrane. The research study indicated the potential use of TBP as a carrier in the SLM system for the selective separation of mercury in trace concentration.
\end{abstract}

KEY WORDS: Removal of mercury(II), Tri n-butyl phosphate, Taguchi method, Supported liquid membrane

\section{INTRODUCTION}

The classical method of design for experimentation of process parameters is time-consuming as it propagates the study through a large set of runs, and also the interaction between the parameters is not considered leading to less reliability [1]. Statistical techniques benefit the user by facilitating a special design that involves less time and energy [2] and is useful by considering the interaction between the parameters. Statistical design of experiments aims to describe the variation under conditions that are hypothesized to reflect the dissimilarity. The "Design of experiments" approach allows one to design a protocol based on the factors that influence a response [3].

The two most extensively used statistical methods are Taguchi design and response surface methodology. Response surface methodology is profusely employed to study the response influenced by several input parameters, to optimize the response [2], and to quantify the relationship between them. Consequently, it finds its usefulness in modeling and analyzing engineering problems [4].

Taguchi's unique experimental design is used for the improvement of a process or quality of a product by combining orthogonal arrays and computation models [5]. The benefit is that it postulates a mean performance characteristic value close to the target [4]. Thereby helps to determine a reliable set of optimal parameters that are not affected by the environmental conditions and noise [1]. It requires fewer experiments within a period to identify the optimum values of the parameters [5] and thus involves low cost compared to other methods [1]. It is useful to identify the cause of problems in a manufacturing process [5], design and improve

*Corresponding author. E-mail: asakithyan@gmail.com

This work is licensed under the Creative Commons Attribution 4.0 International License 
product quality [1]. However, the use of the Taguchi method to investigate and improve SLM studies for the removal of heavy metals is not much reported. Recently, the application of statistical methods for designing the experiments in SLM studies has been attempted for the removal of phenol from wastewater [6, 7].

Heavy metal contamination in aquatic sources is a global issue, which is to be resolved by mankind. Among the various heavy metals, mercury is considered unique as it can easily transform into soil and atmosphere. Though the most common source of mercury is from natural disasters, anthropogenic activities also play a vital role in the contamination of mercury. Acute exposure to mercury causes serious damage to nerves, brain, lungs, and kidneys [8]. Due to the toxic nature of mercury, the environmental protection agency has set the water quality standard of less than $1 \mu \mathrm{gL}^{-1}$ for drinking water whereas, for wastewater discharge, it is about $5 \mu \mathrm{gL}^{-1}$. It is to be noted that conventional water treatment methods are ineffective for trace level concentration of metal ions [9].

SLM, potential technology for the separation and concentration of metal ions in hydrometallurgy, waste recycling process, and wastewater treatment. Most of the research is laboratory-scale studies aiming to establish the feasibility of the membrane setup [10]. Few pilot-scale studies have been reported in wastewater treatment using SLM [11, 12]. Removal of phenol from coal gasification wastewater was tested by Sun et al. [11] using a polypropylene hollow-fiber membrane. They demonstrated the stability of the membrane for 16 days with a removal efficiency of about $75 \%$ [11]. A promising pilot-scale study of copper recovery from spent ammoniacal etching solutions using hollow-fiber SLM has also been reported [12].

SLM is an effective membrane process for the removal of mercury(II) in trace concentration. This assertion could be attributed to its feature of selective separation that could be achieved in a single stage [13]. SLM consists of a hydrophobic microporous polymeric support soaked in an organic carrier that separates the two aqueous phases while allowing for diffusion through the membrane. Low capital cost, low energy requirements, less carrier consumption, and high fluxes are the major advantages of SLM over other configurations of the liquid membrane $[14,15]$. Moreover, SLM generates relatively less amount of wastage in the membrane, in addition to the benefit of offering extraction and re-extraction of carriers in a single step. Thus, being the most promising technology that allows using expensive carriers that is easy to scale-up [16].

Many researchers have studied SLM-based processes for the separation of mercury(II) from various aqueous phases. Use of amine-based carriers such as trioctylamine [14, 17], tetrathia-12crown-4 [18], Aliquat 336 [19] and Cyanex 471 [20] has been reported. Effective transport and removal of mercury(II) were achieved in the studies mentioned above using amine-based carriers, but all these are reportedly hazardous chemicals [21].

In this context, TBP has evolved as a carrier owing to its high extraction capacity, less solubility, high flash point, and low cost $[6,22]$. TBP as a cationic carrier has been successively employed for the extraction of various heavy metals as anionic halo compounds [23, 24]. Extraction studies for mercury ions in acidic solution using TBP in benzene have been demonstrated [25]. They revealed that TBP acquires a positive charge in acidic conditions, and it forms a neutral complex with anionic mercury chloride. Recently, an online flow-injection spectrophotometric method coupled with SLM enrichment was developed for the analysis of trace levels of mercury(II) in wastewater. The study revealed the interaction in acidic solutions between the cationic TBP and anionic mercury ions by the formation of a neutral complex [26]. To date, there are no reported works available for removing mercury(II) using TBP as a carrier in SLM.

In the present work, the removal of mercury(II) using TBP as a carrier by SLM has been investigated. The objective was to determine the effect of factors using the Taguchi method. The factors include feed phase acid $(\mathrm{HCl})$ concentration, strip phase alkali $(\mathrm{NaOH})$ concentration, carrier concentration, and initial feed phase mercury(II) concentration on the removal of 
mercury(II) using SLM. Furthermore, the contribution of each factor on removal efficiency and interaction between them has also been investigated.

\section{Reagents and chemicals}

\section{EXPERIMENTAL}

TBP and stannous chloride were procured from Sisco Laboratory, India. Mercury chloride $\left(\mathrm{HgCl}_{2}\right)$, n-hexane, polyvinyl alcohol, and hydrochloric acid $(\mathrm{HCl})$ were obtained from Merck, India. Sodium hydroxide $(\mathrm{NaOH})$ and rhodamine $\mathrm{B}$ were obtained from Central Drug House, India. Polytetrafluoroethylene (PTFE) membrane was obtained from Sartorius Bio Lab Products, Germany. Aqueous solutions were prepared using double distilled water that did not contain any traces of heavy metals.

\section{Taguchi experimental design}

Four factors were selected from the trial-and-error experiments, to design experiments for the proposed SLM study. Each factor was studied at three levels. They were feed phase acid $(\mathrm{HCl})$ concentration $(0.3,0.5$ and $0.7 \mathrm{M})$, strip phase alkali $(\mathrm{NaOH})$ concentration $(0.2,0.4$ and $0.6 \mathrm{M})$, carrier (TBP) concentration (85, 90 and 95\%), and initial feed phase mercury(II) concentration (1, 10 and $\left.20 \mathrm{mgL}^{-1}\right)$. Statistical designs of experiments followed by data analysis were accomplished by Minitab $17^{\circledR}$ software.

A statistical design of experiments using the factors and their levels mentioned above was employed by Taguchi design methodology. An $\mathrm{L}_{9}$ orthogonal array was designed comprising of nine runs with four factors and three levels. The complete design of the experiments is presented in Table 1.

Table 1. Experiments designed using Taguchi method.

\begin{tabular}{|c|c|c|c|c|}
\hline Run & $\begin{array}{c}\text { Feed phase } \\
\text { concentration } \\
\left(\mathrm{mgL}^{-1}\right)\end{array}$ & $\begin{array}{c}\text { Strip phase } \\
\text { concentration } \\
\left(\mathrm{mgL}^{-1}\right)\end{array}$ & $\begin{array}{c}\text { Carrier concentration } \\
\left(\mathrm{mgL}^{-1}\right)\end{array}$ & $\begin{array}{c}\text { Feed phase mercury(II) } \\
\text { concentration } \\
\left(\mathrm{mgL}^{-1}\right)\end{array}$ \\
\hline 1 & 0.3 & 0.2 & 85 & 1 \\
\hline 2 & 0.3 & 0.4 & 90 & 20 \\
\hline 3 & 0.3 & 0.6 & 95 & 20 \\
\hline 4 & 0.5 & 0.2 & 90 & 1 \\
\hline 5 & 0.5 & 0.4 & 95 & 10 \\
\hline 6 & 0.5 & 0.6 & 85 & 10 \\
\hline 7 & 0.7 & 0.2 & 95 & 20 \\
\hline 8 & 0.7 & 0.4 & 85 & 1 \\
\hline 9 & 0.7 & 0.6 & 90 & \\
\hline
\end{tabular}

Preparation of SLM

PTFE was reported to have better performance concerning other polymeric supports, namely, polyvinylidene difluoride, nylon 66, and polyethylene for the selective separation of mercury(II) in trace levels of concentration [14]. A microporous PTFE polymeric support having a diameter of $47 \mathrm{~mm}$ manufactured by SARTORIUS, Germany, was used for the preparation of SLM. The effective contact area of SLM was $13.2 \mathrm{~cm}^{2}$. The membrane having a pore size of $0.45 \mu \mathrm{m}$, the thickness of $58 \mu \mathrm{m}$, and the porosity of $75 \%$ was immersed in the carrier solution containing TBP in hexane as a diluent (viscosity - $3.46 \mathrm{mPa} . \mathrm{s}$ ). Polymeric support was immersed for $8 \mathrm{~h}$ in the carrier solution to get homogeneous SLM. The pores of the support were filled with an organic carrier by capillary action. After $8 \mathrm{~h}$, the support was taken out of the carrier solution. 
The surface of the support was allowed to drip for few seconds before being placed in the SLM cell.

In SLM studies, the carrier molecule is impregnated by temporary forces. This is confirmed by the SEM analysis. The pores of the membrane were occupied by the TBP molecule through capillary forces.

\section{Experimental setup}

Experiments were carried out using an apparatus made of glass, which is presented in Figure 1. The cell has two cylindrical tanks of equal volume $(250 \mathrm{~mL})$ consisting of feed and strip phase. SLM was placed between the cylinders that were clamped by Teflon holders using screws. Each tank was placed on a magnetic stirrer (Model 841 deep vision Limited, India), and magnetic pellets having a radius of $6 \mathrm{~mm}$ were used for agitation. The rpm controller on both feed sides of the cell was used to stir the solutions.

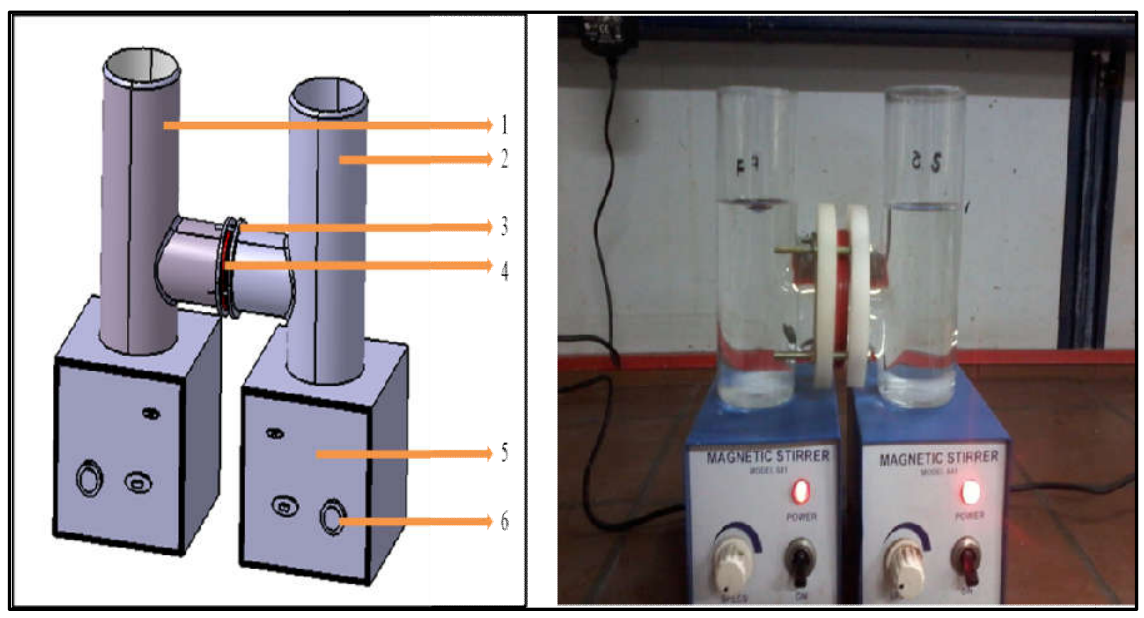

Figure 1. Schematic representation of the SLM cell used for the removal of $\mathrm{Hg}(\mathrm{II})$. (1- feed phase, 2- strip phase, 3-teflon holder, 4- SLM, 5- magnetic stirrer, 6- rpm regulator).

\section{Experiments}

SLM transport experiments were conducted in the SLM apparatus as described above. Feed $(150 \mathrm{~mL})$ and strip $(150 \mathrm{~mL})$ solutions were taken on either side of the SLM cell. Experiments were performed at room temperature $\left(27 \pm 2{ }^{\circ} \mathrm{C}\right)$ with stirring at $300 \mathrm{rpm}$. At regular intervals, equal volumes of the sample were collected from both sides of the cell. The samples were analyzed for the concentration of mercury. All the transport experiments were carried out in triplicates, and the error was within $3 \%$.

\section{Mercury(II) removal performances of liquid membrane}

The concentration of mercury(II) in aqueous samples was analyzed using a visible spectrophotometer (Model: visiscan 167, Systronics India) and verified by cold vapor atomic fluorescence spectrophotometer (CVAFS) (Model: 10.025, Millenium Merlin, PS analytical London). The concentration of mercury(II) from $1-20 \mathrm{mgL}^{-1}$ was analyzed by spectrometric 
method to avoid maximum dilution. In this method, $\mathrm{Hg}(\mathrm{II})$ reacts with Rhodamine $\mathrm{B}$ and iodide to form highly stable tetraiodomercurate(II). The violet colour solution of tetraiodomercurate(II) was measured at $590 \mathrm{~nm}$ [27]. Trace level concentration $\left(0.1-1000 \mu \mathrm{gL}^{-1}\right)$ of mercury(II) was measured using CVAFS with a millennium merlin detector and argon as carrier gas. The $\mathrm{pH}$ of the aqueous solutions was measured using the Elico pH meter (Model: Li 120). SEM images of the membrane were obtained using Carl Zeiss MA15/EVO18 SEM.

\section{Calculations}

The removal efficiency of mercury(II) was calculated using Eq. 1. Here, $\mathrm{C}_{\mathrm{o}}$ is the concentration of mercury(II) initially present in the feed phase, $\mathrm{C}_{t}$ is the concentration of mercury(II) present in the feed phase at time $t$.

Removal efficiency $(\%)=\frac{C_{0}-C_{t}}{C_{0}} \times 100$

\section{RESULTS AND DISCUSSION}

\section{Signal to noise ratio ( $\mathrm{S} / \mathrm{N}$ ratio)}

The concentration of feed phase, strip phase and carrier were fixed based on trial-and-error experiments conducted earlier. The concentration of mercury(II) was chosen based on the literature. Studies have reported maximum concentration of mercury(II) in sea water and fresh waters to be around $1 \mathrm{mgL}^{-1}$ [28]. In the case of industrial wastewaters, the typical concentration of mercury(II) was found to be $10 \mathrm{mgL}^{-1}$ [29]. In our study we have fixed the concentration of mercury(II) in the range from 1 to $20 \mathrm{mgL}^{-1}$ as we aimed to treat waters around $10 \mathrm{mgL}^{-1}$.

Performance of SLM is represented by the desirable (signal) and undesirable (noise) values from the output characteristics of statistical analysis. Taguchi method uses the $\mathrm{S} / \mathrm{N}$ ratio to convert values from the experimental results for determining the optimum combination of controllable factors. $\mathrm{S} / \mathrm{N}$ ratio signifies the ratio of mean to standard deviation. "Larger the better" performance characteristics of the $\mathrm{S} / \mathrm{N}$ ratio were used for obtaining the maximum removal efficiency determined by using Eq. 2. Here, $\mathrm{n}$ denotes the number of repetitions in a trial and $y_{i}$ is the removal efficiency at each experiment [30]. Table 2 shows the removal efficiency of each trial, the mean values, and the $\mathrm{S} / \mathrm{N}$ ratio designed using the Taguchi method. These results were further analyzed to determine the optimum conditions.

$\frac{\mathrm{S}}{\mathrm{N}}$ ratio $=-\log _{10}\left(\frac{1}{\mathrm{n}} \sum_{\mathrm{i}=1}^{\mathrm{n}} \mathrm{y}_{\mathrm{i}}^{2}\right)$

Table 2. Experimental results and statistics.

\begin{tabular}{|c|c|c|c|c|c|}
\hline \multirow{2}{*}{ Run } & \multicolumn{4}{|c|}{ Removal efficiency (\%) } & \multirow{2}{*}{ S/N ratio } \\
\cline { 2 - 5 } & Trial 1 & Trial 2 & Trial 3 & Mean & \\
\hline 1 & 79.11 & 77.54 & 78.37 & 78.34 & 37.88 \\
\hline 2 & 81.99 & 82.49 & 83.78 & 82.75 & 38.36 \\
\hline 3 & 61.82 & 64.62 & 66.16 & 64.20 & 36.15 \\
\hline 4 & 74.18 & 71.15 & 73.34 & 72.89 & 37.25 \\
\hline 5 & 63.18 & 64.34 & 64.15 & 63.89 & 36.11 \\
\hline 6 & 72.16 & 70.96 & 72.73 & 71.95 & 37.14 \\
\hline 7 & 77.98 & 76.28 & 75.42 & 76.56 & 37.68 \\
\hline 8 & 61.45 & 61.94 & 62.15 & 61.85 & 35.83 \\
\hline 9 & 85.87 & 84.67 & 84.39 & 84.98 & 38.58 \\
\hline
\end{tabular}

Bull. Chem. Soc. Ethiop. 2021, 35(2) 
Response values for means of the experiments with maximum removal efficiency are presented in Table 3. The table also shows the characteristic rank associated with each factor. It was observed that carrier concentration is the most influencing factor in the removal studies of mercury ions. The influence of carrier concentration is also confirmed by the main effect plot shown in Figure 2 (b).

Table 3. Response values for $\mathrm{S} / \mathrm{N}$ ratio and mean removal efficiency.

\begin{tabular}{|c|c|c|c|c|c|c|c|c|}
\hline \multirow[t]{2}{*}{ Level } & \multicolumn{2}{|c|}{$\begin{array}{l}\text { Feed phase acid } \\
\text { concentration }\end{array}$} & \multicolumn{2}{|c|}{$\begin{array}{l}\text { Strip phase } \\
\text { concentration }\end{array}$} & \multicolumn{2}{|c|}{ Carrier concentration } & \multicolumn{2}{|c|}{$\begin{array}{l}\text { Feed phase } \\
\text { mercury(II) } \\
\text { concentration }\end{array}$} \\
\hline & $\begin{array}{l}\mathrm{S} / \mathrm{N} \\
\text { ratio }\end{array}$ & $\begin{array}{c}\text { Mean } \\
\text { removal } \\
\text { efficiency }\end{array}$ & $\begin{array}{l}\mathrm{S} / \mathrm{N} \\
\text { ratio }\end{array}$ & $\begin{array}{c}\text { Mean } \\
\text { removal } \\
\text { efficiency }\end{array}$ & $\begin{array}{l}\mathrm{S} / \mathrm{N} \\
\text { ratio }\end{array}$ & $\begin{array}{c}\text { Mean } \\
\text { removal } \\
\text { efficiency }\end{array}$ & $\begin{array}{l}\mathrm{S} / \mathrm{N} \\
\text { ratio }\end{array}$ & $\begin{array}{c}\text { Mean } \\
\text { removal } \\
\text { efficiency }\end{array}$ \\
\hline 1 & 37.46 & 75.11 & 37.60 & 75.93 & 36.95 & 70.73 & 37.52 & 75.72 \\
\hline 2 & 36.83 & 69.58 & 36.77 & 69.52 & 38.06 & 80.20 & 37.73 & 77.10 \\
\hline 3 & 37.36 & 74.46 & 37.29 & 73.69 & 36.65 & 68.22 & 36.41 & 66.33 \\
\hline Delta & 0.63 & 5.53 & 0.84 & 6.41 & 1.42 & 11.98 & 1.31 & 10.77 \\
\hline Rank & \multicolumn{2}{|r|}{4} & \multicolumn{2}{|r|}{3} & \multicolumn{2}{|r|}{1} & \multicolumn{2}{|r|}{2} \\
\hline
\end{tabular}

As indicated in Table 3 and seen in Figure 2, the response of $\mathrm{S} / \mathrm{N}$ ratio and means suggested that carrier concentration was the major influencing factor, among all. Hence, the effect of carrier concentration plays a vital role in the removal efficiency of mercury ions using SLM. A similar trend was observed in the removal efficiency of phenol through SLM [6]. The influence of carrier concentration on removal efficiency may be attributed to the formation of the extractable mercury-TBP complex. In this study, the maximum level of TBP (90\%) has been utilized, and a further increase in the concentration of TBP was not feasible as it resulted in the formation of non-homogenous membranes. This observation may be due to the highly viscous nature of the carrier, which obstructs the transport efficiency of a metal ion complex across SLM [31, 32].

Feed phase mercury(II) concentration was the second influencing factor, as evident from Figure 2. Initially, removal efficiency increases with lower mercury concentration, which may be due to the availability of $\mathrm{Hg}(\mathrm{II})$, thereby facilitating the formation of the complex.

Strip phase concentration and feed phase acid concentration were the less influencing factors on the removal efficiency of mercury ions. $\mathrm{NaOH}$, at higher concentrations, did not lead to an increase in the removal of $\mathrm{Hg}(\mathrm{II})$. This observation may be due to the formation of mercuric oxide $(\mathrm{HgO})$, which precipitated and clogged the pores of the membrane [33]. Figure 2 reveals that increasing the concentration of acid in the feed phase did not influence the removal efficiency. The decrease observed with increasing acid concentration may be attributed to the reduction in the formation of mercury-chloro complexes [34]. The optimum values for the process factors obtained from the ANOVA analysis are $0.3 \mathrm{M}$ of feed phase concentration, 0.2 $\mathrm{M}$ of strip phase concentration, $90 \%$ of carrier concentration and $10 \mathrm{mgL}^{-1}$ of feed phase mercury concentration.

Table 3 presents the $\mathrm{S} / \mathrm{N}$ ratio values and their ranks for each experimental run. From the table, it's clear that carrier concentration has the maximum influence on the $\mathrm{S} / \mathrm{N}$ ratio, also represented in the main effect plot (Figure 2 (a)). 


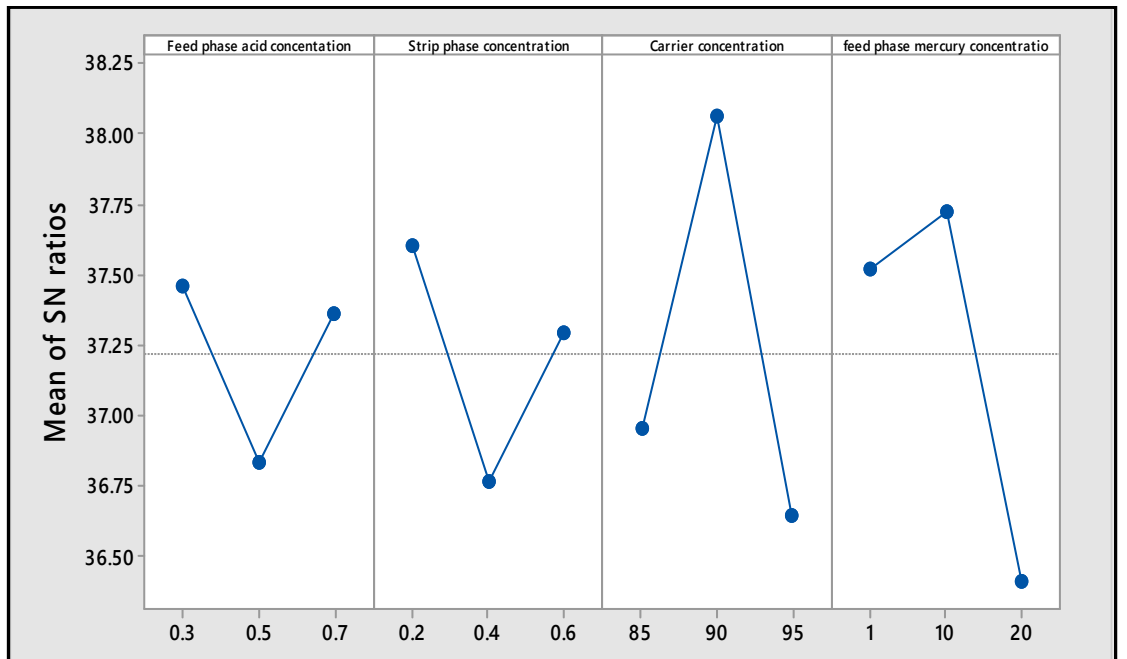

(a)

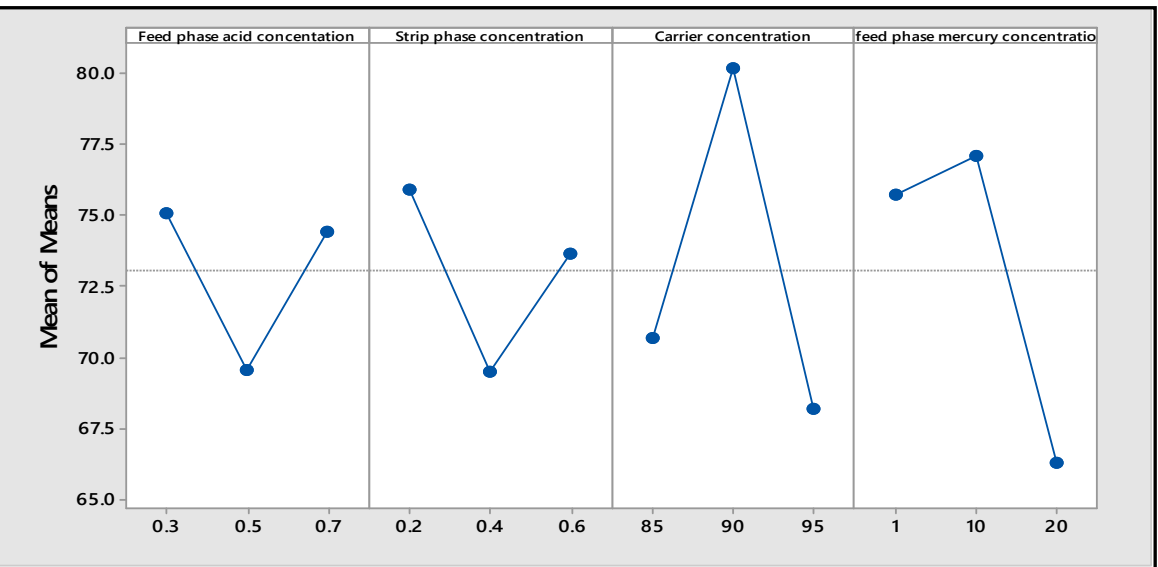

(b)

Figure 2. Main effect plot of each factor on (a) $\mathrm{S} / \mathrm{N}$ ratio (b) removal efficiency.

\section{ANOVA results}

ANOVA is considered a superior tool to determine the optimum combination of various process factors based on their performance [35]. In this study, ANOVA was used to find the significance of process factors on the removal efficiency of mercury(II) across SLM. The optimum condition of the SLM system was determined from the experiments. Experiment with maximum removal efficiency and a very large response of $\mathrm{S} / \mathrm{N}$ ratio was chosen.

The portion of the total variation observed in an experiment and its attribution to each process factor is revealed by the "percentage of contribution". It shows the relative impact of a factor to reduce the variation. The percentage contribution $(\rho)$ of every factor is calculated from its sum of squares $\left(\mathrm{SS}_{\mathrm{Q}}\right)$ divided by the total sum of squares $\left(\mathrm{SS}_{\mathrm{T}}\right)$ of all factors as shown in Eq. 
3 [36]. As seen earlier, carrier concentration showed a maximum $\mathrm{SS}_{\mathrm{Q}}$ value of 245 , followed by feed phase mercury concentration.

$\rho(\%)=\frac{\mathrm{SS}_{\mathrm{Q}}}{\mathrm{SS}_{\mathrm{T}}}$

The percentage contribution of the process factors in the removal efficiency of mercury from aqueous solutions is presented in Figure 3. It can be observed that the maximum contribution of $42 \%$ was by carrier concentration and $36 \%$ by feed phase mercury concentration. Strip phase concentration, feed phase acid concentration, and error percentages were 11,9 and $2 \%$, respectively. Thus, the concentration of carrier in the membrane phase has a significant contribution to the removal of mercury across SLM.

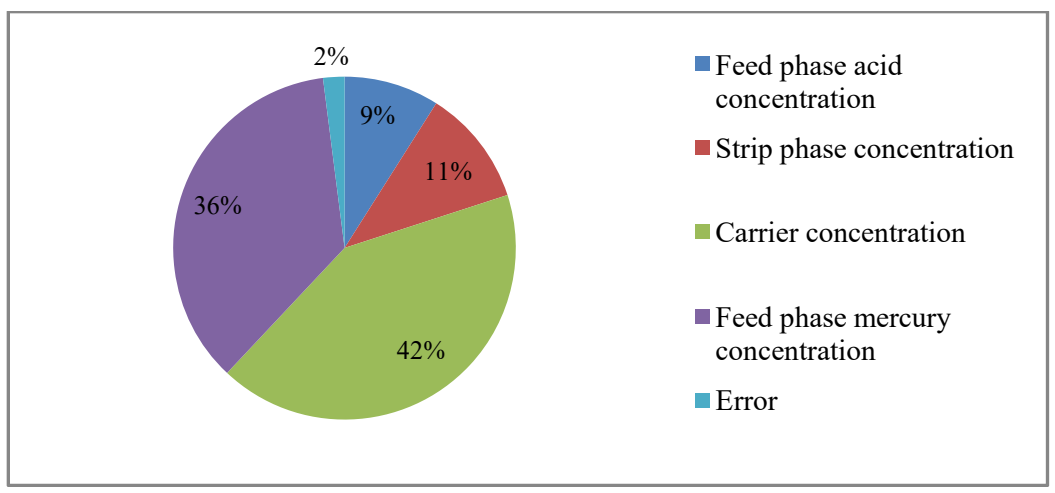

Figure 3. Percentage contribution of process factors.

\section{Confirmation analysis}

Predicted removal efficiency for optimum conditions was calculated using Eq. 4. Here, $\mathrm{T}_{\mathrm{m}}$ is the mean $\mathrm{S} / \mathrm{N}$ ratio, $\mathrm{T}_{\mathrm{o}}$ is the mean $\mathrm{S} / \mathrm{N}$ ratio at the optimum level, and $\mathrm{n}$ is the number of main design parameters that influence the removal efficiency of $\mathrm{Hg}(\mathrm{II})$ across SLM. The predicted removal efficiency of mercury(II) through SLM was calculated to be $92.22 \%$. An experiment was carried out at optimum conditions for $3 \mathrm{~h}$ to confirm the predicted results. Mercury(II) removal efficiency of $91.74 \%$ was obtained from the experiment with the optimum conditions of the parameters.

$\mathrm{T}_{\text {Predicted }}=\mathrm{T}_{\mathrm{m}}+\sum_{\mathrm{i}=1}^{\mathrm{n}}\left(\mathrm{T}_{\mathrm{o}}-\mathrm{T}_{\mathrm{m}}\right)$

Surface analysis of SLM

Morphology of the fresh, carrier impregnated, and the used membrane was studied using SEM analysis. Figure 4(a) displays the microporous nature of the PTFE membrane. The pores of the membrane were seen filled with the carrier, confirming the impregnation process (Figure 4(b)). Figure 4(c) shows the surface changes in the membrane, which was used for 8 cycles of transport experiments. The surface of the membrane was observed to have completely altered due to the formation of the mercury-TBP complex. 


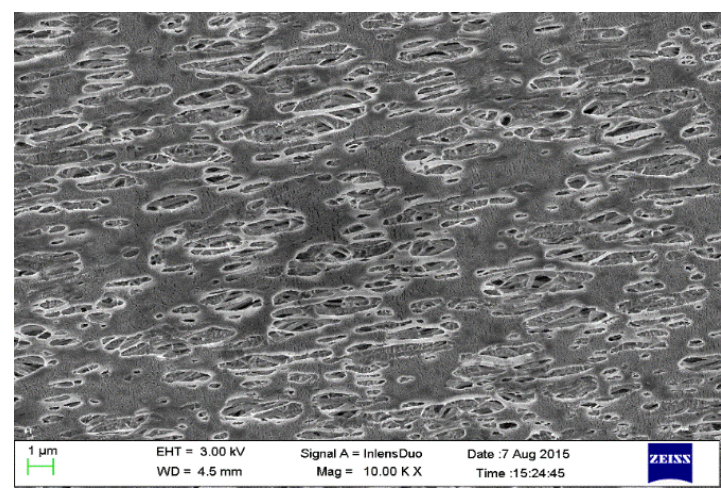

(a)

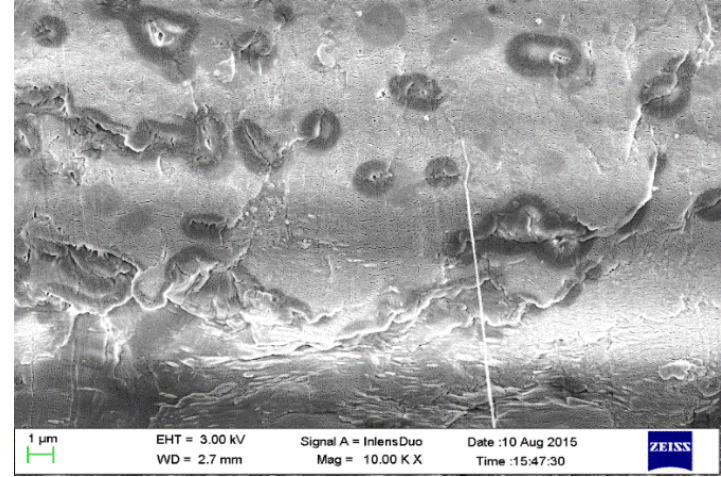

(b)

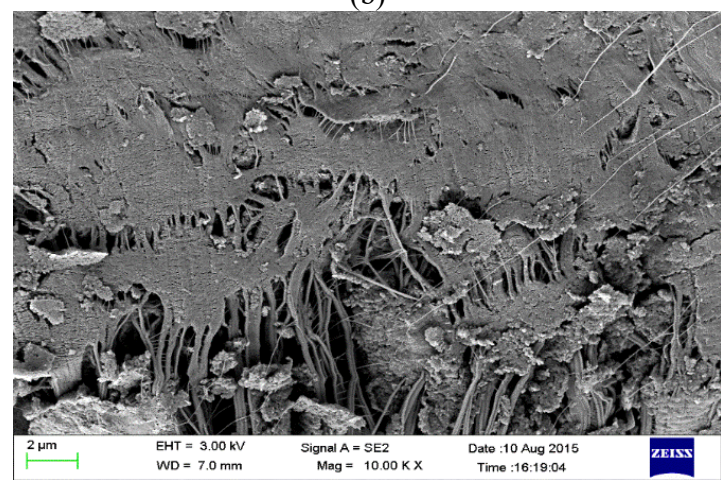

(c)

Figure 4. SEM images of the surface of PTFE support (a) fresh, (b) after immersion into carrier and (c) used SLM after $8^{\text {th }}$ run.

\section{Transportation mechanism}

Transport of metal ions through SLM is mainly of two types, namely, counter transport and cotransport mechanisms. Transport that is carried out in opposite direction with the presence of metal ions in the feed phase and the counter ions in strip phase is known as counter transport. 
On the other hand, metal ions transported with the concentration gradient of the co-ions present in the feed and strip phase is called a co-transport mechanism [37]. In this experimental study, the mercury(II) transport was driven by the concentration gradient between the feed and strip phases. Mercury(II) was transported against its concentration gradient as the driving force. Transportation of mercury(II) across SLM takes place through the following steps:

(1) The feed phase contains mercury(II) and the addition of $\mathrm{HCl}$ makes room for the free availability of chloride and hydrogen ions. The chloride ions form chloro compounds with mercury(II) (Eq. 5).

$\mathrm{Hg}^{2+}+4 \mathrm{Cl}^{-} \leftrightarrow \mathrm{HgCl}_{4}^{2-}$

(2) TBP in the membrane phase combines with the protons in the feed phase and forms a cationic complex, as given in Eq. 6.

$(\mathrm{RO})_{3} \mathrm{PO}+\mathrm{H}^{+} \leftrightarrow\left((\mathrm{RO})_{3} \mathrm{PO}\right) \mathrm{H}^{+}$

(3) Proton acquired TBP forms a complex when it reacts with the mercury chloride anion, which is present in the feed phase (Eq. 7) [25, 26]

$2\left((\mathrm{RO})_{3} \mathrm{PO}\right) \mathrm{H}^{+}+\mathrm{HgCl}_{4}^{2-} \leftrightarrow \mathrm{HgCl}_{4}^{2-} \cdot 2\left((\mathrm{RO})_{3} \mathrm{PO}\right) \mathrm{H}^{+}$

(4) Mercury-TBP complex reacts with $\mathrm{NaOH}$ available in the strip phase and forms mercuric(II) chloride with the separation of TBP as shown in Eq. 8.

$\mathrm{HgCl}_{4}^{2-} \cdot 2\left((\mathrm{RO})_{3} \mathrm{PO}\right) \mathrm{H}^{+}+\mathrm{NaOH} \leftrightarrow \mathrm{HgCl}_{4}^{2-}+2(\mathrm{RO})_{3} \mathrm{PO}+\mathrm{H}_{2} \mathrm{O}+\mathrm{NaCl}$

TBP thus obtained diffuses back to the membrane phase, and the transport mechanism that is mentioned above continues as a cycle. The whole process with the steps involved is depicted schematically in Figure 5.

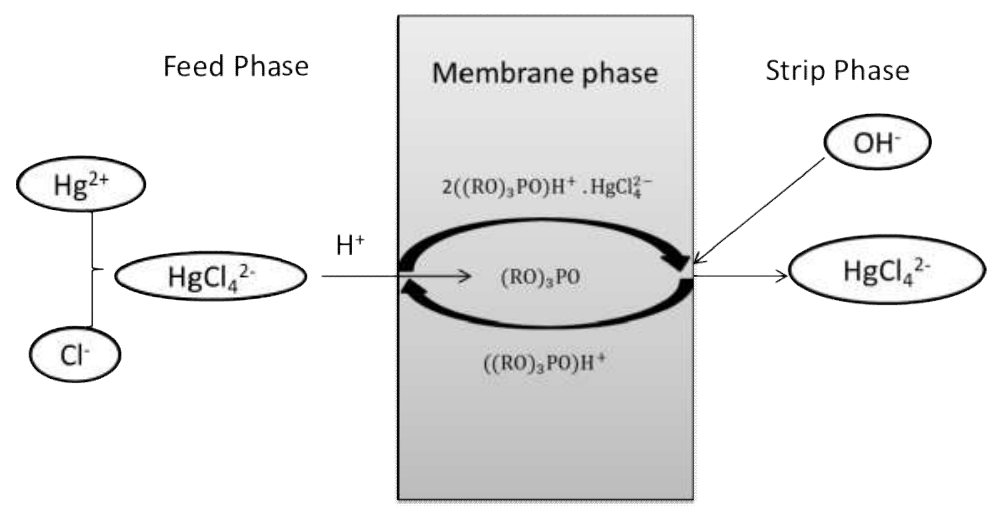

Figure 5. Schematic diagram of the Co-transport mechanism of mercury(II) ions through SLM.

\section{Concentration profile}

Transport studies were carried out with optimized parameters to study the concentration profile for the removal of mercury(II). The experiment was carried out for $3 \mathrm{~h}$ to attain maximum removal of mercury(II). The concentration profile of mercury(II) in all three phases, namely feed phase, strip phase, and membrane phase was determined, and the results are shown in Figure 6. In this experiment, $10 \mathrm{mgL}^{-1}$ of mercury(II) taken in the feed side was reduced 
gradually due to its transport from feed to strip side. On the other hand, mercury(II) concentration increased after stripping as mercury(II) chloride. In the meantime, SLM accumulated some mercury(II), and its concentration slightly reduced as time progressed.

The experimental data fitted well with the first-order rate kinetics as indicated in Figure 7 , where the rate of transport of $60 \%$ mercury(II) was attained gradually in $7200 \mathrm{~s}$ with maximum efficiency around $3600 \mathrm{~s}$. Mass transfer rate through SLM was calculated using Danesi equation (Eq. 9), in which $\mathrm{A}$ is the effective membrane area $\left(\mathrm{m}^{2}\right), \mathrm{k}$ is the mass transfer coefficient, $\mathrm{V}$ is the volume of feed solution $\left(\mathrm{m}^{3}\right)$, $t$ is the specified separation time, $\mathrm{C}_{\mathrm{i}}$ is the initial mercury(II) concentration $\left(\mu \mathrm{gL}^{-1}\right)$, and $\mathrm{C}_{\mathrm{t}}$ is mercury(II) concentration $\left(\mu \mathrm{gL}^{-1}\right)$ in the feed phase at time $\mathrm{t}$. The mass transfer coefficient for the removal of mercury(II) was calculated to be $5.26 \times 10^{-4} \mathrm{~m} / \mathrm{s}$ at optimum conditions.

$\ln \frac{C_{t}}{C_{o}}=-\left(\frac{K A}{V}\right) t$

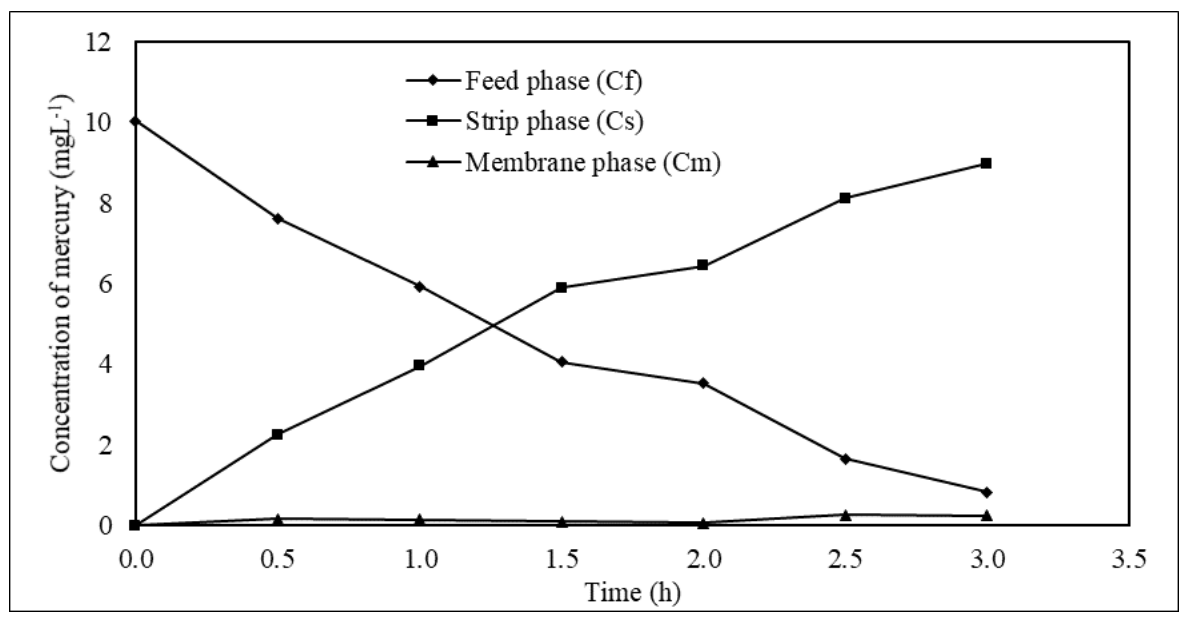

Figure 6. Concentration profile of mercury(II) removal efficiency through SLM.

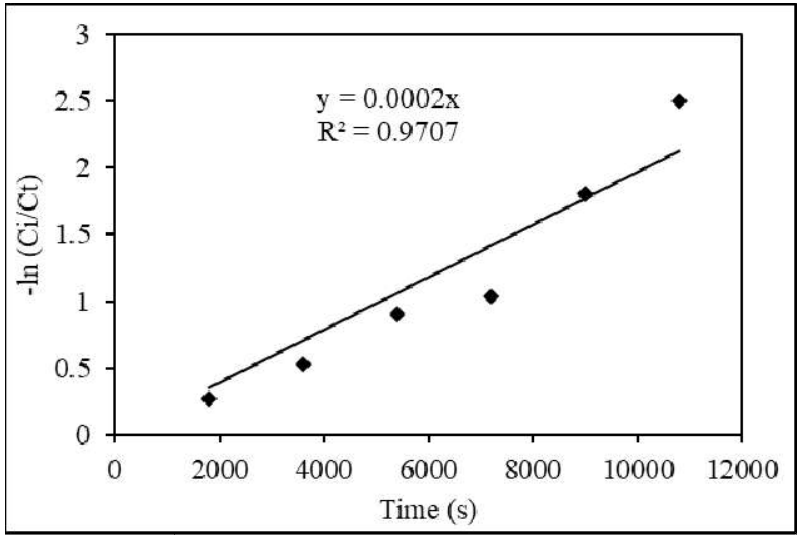

Figure 7. Kinetic plot for transport of mercury(II) across SLM.

Bull. Chem. Soc. Ethiop. 2021, 35(2) 


\section{CONCLUSION}

TBP based SLM system for the removal of mercury was successfully demonstrated by applying Taguchi method to examine the effects of parameters on percentage removal of mercury(II) in trace level of concentration $\left(10 \mathrm{mgL}^{-1}\right)$. The maximum removal efficiency of $91.7 \%$ for mercury was attained using this system at optimum conditions. Taguchi method gave a clear indication of the influence of various factors in the removal of mercury ions using SLM. Among the factors studied, namely, feed phase acid concentration, strip phase alkali concentration, carrier concentration and initial feed phase mercury concentration, the latter two factors were found to have profound effects on the removal process. Thus, the present study elucidated the use of a TBP based SLM system for the potential treatment of aqueous solutions contaminated with trace concentrations of mercury.

\section{ACKNOWLEDGEMENT}

Author Mr. A. Saravanan is highly thankful to the Basic Scientific Research Fellowship granted by University Grants Commission, Government of India, New Delhi, for the financial assistance and thankful to Management NLC India Limited, Neyveli for their immense support.

\section{REFERENCES}

1. Kargari, A.; Kaghazchi, T.; Sohrabi, M.; Soleimani, M. Application of experimental design to emulsion liquid membrane pertraction of gold(III) ions from aqueous solutions. Iran. J. Chem. Eng. 2006, 3, 77-91.

2. Bezerra, M.A.; Santelli, R.E.; Oliveira, E.P.; Villar, L.S.; Escaleira, L.A. Response surface methodology as a tool optimization in analytical chemistry. Talanta 2008,76, 965-977.

3. Ashengroph, M.; Nahvi, I.; Amini, J. Application of Taguchi design and response surface methodology for improving conversion of isoeugenol into vanillin by resting cells of Psychrobacter sp. CSW4. Iran. J. Pharm. Res. 2013, 12, 411-421.

4. Muhammad, N.; Manurang, Y.H.P.; Hafidzi M.; Abas, S.K.; Tham G.; Haruman E. Optimization and modeling of spot-welding parameters with simultaneous multiple response consideration using multiple-objective Taguchi method and RSM. J. Mech. Sci. Technol. 2012, 26, 2365-2370.

5. Jou, Y.; Lin, W.; Lee, W.; Yeh T. Integrating the Taguchi method and response surface methodology for process parameter optimization of the injection molding. Appl. Math. Inf. Sci. 2014, 8, 1277-1285

6. Kazemi, P.; Peydayesh, M.; Bandegi, A.; Mohammadi, T.; Bakhtiari, O. Stability and extraction study of phenolic wastewater treatment by supported liquid membrane using tributyl phosphate and sesame oil as liquid membrane. Chem. Eng. Res. Des. 2014, 92, 375383.

7. Ng, Y.S.; Jayakumar, N.S.; Hashim, M.A. Behavior of hydrophobic ionic liquids as liquid membranes on phenol removal: Experimental study and optimization. Desalination 2011, 278, 250-258.

8. Shafeeq, A.; Muhammed, A.; Sarfraz, W.; Taqeer, A.; Rashid, S.; Rafiq, M.K. Mercury removal techniques for industrial wastewater. World Acad. Sci. Eng. Technol., 2012, 6, $1180-1183$.

9. Suren, S.; Pancharoen, U. Selective separation of lead and mercury ions from synthetic produced water via a hollow fiber supported liquid membrane, World Acad. Sci. Eng. Technol. 2012, 6, 1715-1720. 
10. Padwal, N.; Prakash, S.S.; Thakkar, S.; Deshpande, T. Supported liquid membrane technology: Advances and review of its applications. Indian J. Adv. Chem. Sci. 2018, 6, 118129.

11. Sun, H.; Yao, J.; Cong, H.; Li, Q.; Li, D.; Liu, B. Enhancing the stability of supported liquid membrane in phenols removal process by hydrophobic modification. Chem. Eng. Res. Des. 2017, 126, 209-216.

12. Yang, Q.; Kocherginsky, N.M. Copper recovery and spent ammoniacal etchant regeneration based on hollow fiber supported liquid membrane technology: From bench-scale to pilotscale tests. J. Membrane Sci. 2006, 286, 301-309.

13. Yang X.J.; Fane, A.G.; Macnaughton, S. Removal and recovery of heavy metals from wastewater by supported liquid membrane. Water Sci. Technol. 2001, 43, 341-348.

14. Chakrabarty K.; Saha, P.; Ghoshal, A.K. Simultaneous separation of mercury and lignosulfonate from aqueous solution using supported liquid membrane. J. Membrane. Sci. 2010, 346, 37-44.

15. Ersoz, M., Transport of mercury through liquid membranes containing calixarene carriers. Adv. Colloid Interface Sci. 2007, 134-135, 96-104.

16. Kocherginsky, N.M.; Yang, Q.; Seelam, L. Recent advances in supported liquid membrane technology. Sep. Purif. Technol. 2007, 53, 171-177.

17. Pancharoen, U.; Somboonpanya, S.; Chaturabul, S.; Lothongkum, A.W. Selective removal of mercury as $\mathrm{HgCl}_{4}^{2-}$ from natural gas well produced water by TOA via HFSLM. J. Alloys Compd. 2010, 489, 72-79.

18. Shamshipur, M.; Hashemi, O.R.; Lippolis, V.A. Supported liquid membrane system for simultaneous separation of silver(I) and mercury(II) from dilute feed solutions. J. Membrane Sci. 2006, 282, 322-327.

19. Fontas, C.; Hidalgo, M.; Salvado, V.; Antico E. Selective recovery and preconcentration of mercury with a benzoylthiourea-soild supported liquid membrane system. Anal. Chim. Acta 2005, 547, 255-261.

20. Lothongkum, A.W.; Suren, S.; Chaturabul, S.; Thamphipit, N.; Pancharoen, U. Simultaneous removal of arsenic and mercury from natural-gas-co-produced water from the Gulf of Thailand using synergistic extractant via HFSLM. J. Membrane Sci. 2011, 369, 350358.

21. Venkateswaran, P.; Palanivelu, K. Recovery of phenol from aqueous solution by supported liquid membrane using vegetable oils as liquid membrane. J. Hazard. Mater. 2006, 131, 146-152.

22. Zhang, W.; Liu, J.; Ren, Z.; Wang, S.; Du, C.; Ma, J. Kinetic study of chromium(VI) facilitated transport through a bulk liquid membrane using tri-n-butyl phosphate as carrier. Chem. Eng. J. 2009, 150, 83-89.

23. Sadeghi, N.; Alamdari, E.K. A new approach for monitoring and controlling the extraction of gold by tri-butyl phosphate from chloride media. Miner. Eng. 2016, 85, 34-37.

24. Sonmez, E.; Sonmez, F.; Kumbasar, R.A.; Eyupoglu, V. Synergistic and selective extraction of $\mathrm{Cd}^{2+}$ from acidic solution containing $\mathrm{Cd}^{2+}, \mathrm{Co}^{2+}, \mathrm{Ni}^{2+}$ by triisooctylamine (TIOA) and triisobutyl phosphate(TBP). J. Ind. Eng. Chem. 2012, 18, 1286-1292.

25. Sato, T.; Enokida, T.; Noguchi, Y. Liquid-liquid extraction of mercury(II) from hydrochloric acid solutions by tributyl phosphate. Solvent Extr. Res. Dev. Jpn. 2002, 9, 1-11.

26. Xiao, X.; Yang, N.; Wang, Z.; Huang, Y. Determination of trace mercury(II) in wastewater using on-line flow injection spectrophotometry coupled with supported liquid membrane enrichment. Anal. Methods 2016, 8, 582-586.

27. Loo, A.Y.Y.; Yap, P.L.; Kutty, M.; Timpe, O.; Behrens, M.; Hamid, S.B.A. Spectrometric determination of mercury with iodide and rhodamine B. Sains. Malays. 2012, 41, 213-218.

28. Lin, H.O. Mercury pollution in Kodaikanal caused by a thermometer factory spill in 2001. Biology in South India 2015, A6-A11. 
29. Zambrano, J.B.; Laborie, S.; Viers, P.; Rakib, M.; Durand, G. Mercury removal and recovery from aqueous solutions by coupled complexation-ultrafiltration and electrolysis. $J$. Membrane Sci. 2004, 229, 179-186.

28. Puviyarasan, M.; Senthilkumar, V.S. Optimization of friction stir process parameters in fabricating AA6061/SiCp Composites. Procedia Eng. 2012, 38, 1094-1103.

30. Chaudry, A.M.; Bhukari, N.; Mazhar, M.; Abbasi, W. Coupled transport of chromium(III) ions across triethanolamine/cyclohexanone based supported liquid membranes for tannery waste treatment. Sep. Purif. Technol. 2007, 55, 292-299.

31. Sangtumrong, S.; Ramakul, P.; Satayaprasert, C.; Pancharoen, U.; Lothongkum, A.W. Purely separation of mixture of mercury and arsenic via hallow fiber supported liquid membrane. J. Ind. Eng. Chem. 2007, 13, 751-756.

32. Li, Q.; Liu, Q.; Wei, X. Separation of mercury through an emulsion liquid membrane. Talanta 1996, 43, 1837-1842.

33. Baba, Y.; Umezaki, Y.; Udea, T.; Inoue, K. Extraction equilibria of mercury(II) from hydrochloric acid with trialkylphosphine sulfides. Bull. Chem. Soc. Jpn. 1986, 59, 38353839.

29. Mohammadi, T.; Moheb, A.; Sadrzadeh, M.; Razmi, A. Separation of copper ions by electrolysis using Taguchi experimental design. Desalination 2004, 169, 21-31.

34. Subromonian, S.; Milkey, K.R.; Samsudin, A.R.; Dubey, A.K.; Kidd, P. Comparison between Taguchi method and response surface methodology (RSM) in modeling $\mathrm{CO}_{2}$ laser machining. Jordan J. Mech. Indust. Eng. 2014, 8, 35-42.

35. Agreda, D.E.; Diaz, I.G,; Lopez, F.A.; Alguacil, F.J. Supported liquid membranes technologies in metals removal from liquid effluents. Rev. Metal. Madrid 2011, 47, 146-168. 